\title{
Studi Pemanfaatan Biogas dari Limbah Rumah Potong Hewan untuk Mendukung Ketahanan Energi di Kota Bandung
}

\author{
Anita Juraida ${ }^{1}$ \\ Universitas Widyatama, Bandung, Indonesia \\ Yudha Prambudia \\ Universitas Widyatama, Bandung, Indonesia
}

\author{
Ari Rahman \\ Universitas Pertamina, Jakarta, Indonesia
}

Artikel Masuk : 28 Agustus 2018

Artikel Diterima : 13 Februari 2019

Tersedia Online : 30 April 2019

\begin{abstract}
Abstrak: Permintaan kebutuhan energi, khususnya energi listrik untuk berbagai macam aktivitas, terus meningkat seiring dengan pertumbuhan populasi perkotaan. Saat ini sebagian besar pasokan energi masih didominasi oleh sumber bahan bakar fosil. Seiring meningkatnya penggunaan bahan bakar fosil, gas rumah kaca yang dihasilkan juga meningkat, yang berdampak pada terjadinya pemanasan global. Selain itu pertumbuhan penduduk juga berdampak pada peningkatan volume limbah yang dihasilkan dari kegiatan industri dan aktivitas rumah tangga. Penelitian ini menerapkan konsep waste to energy dengan mengestimasi potensi energi terbarukan dari limbah Rumah Potong Hewan (RPH) di Kota Bandung, Indonesia yang selama ini belum termanfaatkan secara optimal penggunaannya. Penelitian ini bertujuan untuk mengestimasi seberapa besar potensi biogas dari limbah hewan (sapi), terdiri dari limbah darah, rumen dan kotoran yang dapat digunakan untuk kebutuhan energi listrik di Kota Bandung. Metode yang digunakan untuk memprediksi produksi biogas adalah dengan teknik observasi langsung di lapangan, wawancara, dan kajian literatur. Lokasi penelitian dilakukan di RPH milik Pemerintah dan swasta di Kota Bandung, yang tersebar di area Ciroyom, Cirangrang, dan Regol. Hasil penelitian menunjukkan terdapat potensi biogas sebesar $139.977 \mathrm{~m}^{3} /$ tahun atau jika dikonversikan ke dalam energi listrik adalah 658 $\mathrm{MWh} /$ tahun. Guna mendukung ketahanan energi di Kota Bandung, biogas dari rumah potong hewan ini dapat berkontribusi sebesar 49,8\% untuk pasokan listrik rumah tangga atau 16,7\% dari total pasokan listrik di Kota Bandung. Temuan penelitian ini diharapkan dapat menjadi bagian dari proyek percontohan untuk lingkup penelitian yang lebih besar guna membangun program sustainable city di masa yang akan datang.
\end{abstract}

Kata Kunci: biogas; energi listrik; Kota Bandung; limbah rumah potong hewan; sapi

Abstract: Energy demand, particularly electricity for many activities, increases in line with the growth of urban population. Nowadays, most of energy supply in urban area is still dominated

\footnotetext{
1 Korespondensi Penulis: Universitas Widyatama, Bandung, Indonesia

email: anita.juraida@widyatama.ac.id
} 


\section{Studi Pemanfaatan Biogas dari Limbah Rumah Potong Hewan ...}

by the fossil fuel sources. As the use of fossil fuel increases, so does the greenhouse gas emission closely linked to global warming effects. Moreover, population growth also implies on waste production resulted from industrial and domestic activities. This paper applies waste to energy concept by estimating potential renewable energy from the slaughterhouse waste in Bandung City, Indonesia. This study is aimed to predict the potential contribution of waste from cattle, consisting of blood, rumen and feces from the slaughterhouses for biogas production. This research applies direct observation technique, interview and literature review methods. The location of this research was at the public and private slaughterhouses in Ciroyom, Cirangrang, and Regol of the Bandung City. The results showed that biogas could be produced by $139,977 \mathrm{~m}^{3} /$ year equivalent to $658 \mathrm{MWh} /$ year of electricity production. To support the city's energy security, this potential energy source may contribute around $49.8 \%$ of the household electricity supply equivalent to $16.7 \%$ of the total electricity supply in Bandung City. This finding could be beneficial to the larger pilot study concerning the sustainable city program.

Keywords: Bandung City; biogas; cattle; electricity; slaughterhouse wastes

\section{Pendahuluan}

Indonesia merupakan negara keempat dengan jumlah penduduk terbesar di dunia setelah China, India, dan Amerika. Jumlah penduduk Indonesia pada tahun 2016 sebesar 266 juta penduduk (Worldmeters, 2018). Pertumbuhan penduduk di Indonesia selalu meningkat setiap tahunnya. Pada tahun 2017, pertumbuhan penduduk di Indonesia mencapai $1,36 \%$ atau setara dengan 3,57 juta orang (BPS, 2017). Pertumbuhan penduduk secara langsung berdampak pada peningkatan kebutuhan pangan dan penyediaan energi. Pertambahan penduduk kota melahirkan berbagai isu di bidang ekonomi, sosial dan lingkungan yang menyebabkan tingkat keberlanjutan (sustainability) kehidupan perkotaan semakin menurun.

Populasi dunia saat ini secara bertahap semakin terkonsentrasi di daerah perkotaan. Hal ini menyebabkan perkotaan berperan besar dalam penggunaan energi dan emisi gas rumah kaca. Pada tahun 2030 diperkirakan bahwa 4,6 miliar orang akan tinggal di perkotaan (Ho, Matsuoka, Simson, \& Gomi, 2013; IPCC, 2007). Peningkatan populasi diiringi dengan peningkatan kegiatan ekonomi dan sosial di perkotaan berdampak pada peningkatan konsumsi dan emisi gas rumah kaca (Rawung, 2015; Yuliana, 2017).

Di Indonesia, kebijakan rendah karbon secara bertahap telah diadopsi oleh beberapa kota (Tarigan et al., 2016). Pelaksanaan kebijakan dilakukan dengan interpretasi dan pendekatan yang beragam, termasuk di antaranya efisiensi energi, pembangunan berkelanjutan, dan adopsi energi terbarukan. Salah satu permasalahan terkait dengan pemenuhan kebutuhan listrik. Dewan Energi Nasional (2016) menyebutkan bahwa tingkat pertumbuhan permintaan listrik telah meningkat rata-rata $7,1 \%$ per tahun. Pasokan energi listrik di Indonesia masih didominasi oleh bahan bakar fosil, terutama dari pembakaran batu bara (IEA, 2012). Namun, proses pembakaran batu bara rentan berdampak terhadap pencemaran udara. Gas beracun seperti sulfur dioksida $\left(\mathrm{SO}_{2}\right)$ yang dilepas ke lingkungan dapat bereaksi dengan uap air di udara membentuk asam sulfat $\left(\mathrm{H}_{2} \mathrm{SO}_{4}\right)$ yang dapat menyebabkan hujan asam. Selain itu, bahan bakar fosil dikategorikan sebagai sumber energi tidak terbarukan yang akan habis jika digunakan terus-menerus. Kebutuhan energi terbarukan menjadi penting untuk melindungi ketahanan energi di Indonesia.

Laju pertumbuhan masyarakat juga berkorelasi positif dengan laju timbulan sampah (volume sampah atau berat sampah yang dihasilkan dari suatu sumber pada suatu satuan waktu), khususnya sampah rumah tangga. Semakin banyak jumlah penduduk, jumlah sampah rumah tangga yang dihasilkan pun semakin meningkat. Menurut Pariatamby \& Fauziah (2013), jenis sampah rumah tangga yang paling dominan ditimbulkan di negara 
berkembang adalah sampah organik. Selain sampah organik dari sampah rumah tangga, sampah organik pun banyak diperoleh dari limbah peternakan. Selama ini, limbah peternakan sering dibuang begitu saja sehingga memberikan beban untuk tempat pembuangan akhir, padahal limbah peternakan mempunyai efek negatif terhadap lingkungan dan kesehatan (Martinez, Dabert, Barrington, \& Burton, 2009). Penanganan yang tidak tepat akan menyebabkan pencemaran tanah dan air berupa melemahnya daya dukung tanah dan munculnya patogen (Rachmawati, 2000). Dalam lingkup penelitian yang lebih besar, sejumlah kerugian dapat ditimbulkan oleh adanya limbah peternakan, padahal apabila dikelola secara optimal, limbah ini dapat diubah menjadi energi, atau yang disebut dengan pendekatan Waste to Energy.

Proses pemanfaatan potensi energi terbarukan dilakukan sejak terjadinya penipisan bahan bakar fosil akibat peningkatan konsumsi energi masyarakat serta munculnya isu lingkungan hidup (Omari, Kichonge, John, Njau, \& Mtui, 2014; Ramachandra, Kamakshi, \& Shruthi, 2004). Sedikitnya pada tahun 2012, energi terbarukan berkontribusi sebanyak $13,2 \%$ terhadap total sumber energi di dunia (IEA, 2012). Salah satu sumber limbah yang berpotensi besar untuk penerapan pendekatan Waste to Energy adalah limbah organik dari rumah potong hewan (RPH). Limbah organik yang berupa darah, jeroan hewan (rumen) dan kotoran hewan dapat diubah menjadi sumber energi terbarukan (renewable energy) berupa biogas. Teknik yang biasa digunakan dalam mengubah sampah menjadi energi (khususnya biogas) adalah biochemical conversion, yang mengubah sampah dengan bantuan mikroba (bakteri metanogenik) sehingga material akan terurai secara alami dalam kondisi anaerobic (Elizabeth \& Rusdiana, 2011; Omari et al., 2014).

Proses mengubah limbah ternak menjadi sumber energi biogas merupakan tindakan yang tepat dan menguntungkan karena mampu mencegah penyebaran penyakit akibat patogen yang berada di hewan ternak, menjaga kelestarian alam dengan cara mengurangi efek gas rumah kaca, serta dapat dimanfaatkan guna menghasilkan panas dan energi listrik (Elizabeth \& Rusdiana, 2011; Herawati, 2012; Hozairi, Bakir, \& Buhari, 2012; Setiawan, 2008). Penelitian terkait biogas dari ternak sapi bukanlah penelitian baru. Sebelumnya terdapat beberapa penelitian yang pernah dilakukan baik secara laboratorium eksperimen maupun model estimasi. Hal ini dilakukan untuk mengetahui potensi biogas yang dapat dihasilkan dari sapi, baik berasal dari limbah darah sapi, rumen maupun kotoran sapi.

Opurum, Nweke, Nwanyanwu, \& Orji (2017) mengubah 10 liter limbah darah sapi dan limbah ikan dengan menggunakan anaerobic digester system selama 30 hari. Biogas yang dihasilkan adalah 19,56 $\mathrm{dm}^{3}$. Recebli, Selimli, Ozkaymak, \& Gonc (2015) memanfaatkan limbah dari kotoran 70 ekor sapi dengan melakukan eksperimen menggunakan tangki fermentasi. Proses fermentasi menggunakan suhu $307{ }^{\circ} \mathrm{K}$ tersebut menghasilkan biogas sebesar $6,33 \mathrm{~m}^{3}$ per hari. Sejalan dengan penelitian lainnya, Ihsan, Bahri, \& Musafira (2013) membuat biogas dengan menggunakan $10 \mathrm{~kg}$ limbah rumen sapi dan limbah cair tempe dengan cara eksperimen. Jumlah biogas yang dihasilkan sebesar 21,57 mL.

Potensi limbah sapi juga dapat dihitung menggunakan estimasi. Di Iran, Afazeli, Jafari, Rafiee, \& Nosrati (2014) menghitung potensi biogas dari darah dan rumen. Potensi biogas yang dapat dicapai yaitu 9,18 juta $\mathrm{m}^{3} /$ tahun dan 12,96 juta $\mathrm{m}^{3} /$ tahun. Selain itu, Dehkordi, Shamsabadi, Pishkar, \& Nafchi (2015) juga menunjukkan potensi biogas sebesar $0,744 \mathrm{~m}^{3}$ per hari dari limbah kotoran sapi. Biogas yang dihasilkan dapat bermanfaat menjadi energi, yaitu energi panas, energi untuk memasak, dan listrik (Dehkordi et al., 2015; Owusu \& Banadda, 2017; Saputri, Yuwono, \& Mahmudsyah, 2014).

Perbedaan penelitian ini dengan penelitian sebelumnya adalah penelitian ini memanfaatkan seluruh potensi yang dapat diestimasi untuk menjadi biogas, yaitu darah, rumen, dan kotoran. Selain itu, pemanfaatan ini melibatkan RPH milik Pemerintah dan swasta di Kota Bandung, sehingga hasil dari penelitian menjadi lebih representatif guna mendukung ketahanan energi perkotaan. 
Bandung merupakan salah satu kota besar di Indonesia yang memiliki luas 167,31 $\mathrm{km}^{2}$ (BPS Kota Bandung, 2017), dengan populasi penduduk sebanyak 2.490 .622 orang (BPS Kota Bandung, 2016). Saat ini, kebutuhan energi di Kota Bandung masih mengandalkan energi fosil, sedangkan permintaan energi setiap tahun selalu meningkat. Berdasarkan data PT PLN (Persero) Distribusi Jawa Barat Cabang Bandung (2016), sebaran penggunaan listrik di Kota Bandung adalah untuk kebutuhan rumah tangga (37,99\%), industri $(30,17 \%)$, komersial $(25,24 \%)$, sosial $(3,92 \%)$, publik $(2,63 \%)$, transportasi/komunikasi/tenaga kerja $(0,05 \%)$. Oleh karena itu, diperlukan cara untuk meningkatkan suplai energi, salah satunya adalah dengan cara mengubah limbah organik yang berupa darah, rumen dan kotoran hewan menjadi sumber energi terbarukan berupa biogas dari RPH di Kota Bandung. Adanya energi terbarukan dapat mendukung ketahanan energi dalam kota, khususnya Kota Bandung.

Penelitian ini bertujuan untuk mengestimasi seberapa besar potensi biogas dari limbah hewan (sapi), terdiri dari limbah darah, rumen dan kotoran yang dapat digunakan untuk kebutuhan energi listrik di Kota Bandung. Objek dari penelitian ini adalah semua limbah sapi yang dapat dimanfaatkan untuk produksi biogas, meliputi darah, kotoran, dan rumen. Kebaruan dari penelitian ini adalah penelitian ini tidak hanya menghitung potensi biogas dari limbah sapi RPH milik Pemerintah dan Swasta Kota Bandung saja, tetapi juga menghitung berapa besar potensi energi listrik yang dapat dihasilkan dari biogas. Selanjutnya, data tersebut dibandingkan dengan rata-rata penggunaan energi listrik di Kota Bandung untuk mengetahui seberapa besar energi listrik dari biogas dapat menyediakan kebutuhan energi listrik kota. Tentunya hal ini sejalan dengan program ketahanan energi Kota Bandung, khususnya dari aspek ekstensifikasi penggunaan energi terbarukan. Temuan penelitian ini merupakan bagian dari pilot project untuk lingkup studi yang lebih besar dalam rangka membangun program kota berkelanjutan di masa yang akan datang.

\section{Metode Penelitian}

Kegiatan penelitian ini dilaksanakan pada RPH milik Pemerintah Kota Bandung, terletak di area Ciroyom dan Cirangrang. Serta RPH milik swasta yaitu di area Regol. Pengumpulan data dilakukan melalui observasi langsung, wawancara dan tinjauan pustaka. Penelitian dilakukan selama satu bulan yang dibagi ke dalam empat minggu. Dari hasil penelitian terdapat 47 sapi lokal dan 1.004 sapi impor di RPH Ciroyom. Sementara itu, di RPH Cirangrang dan Regol tidak terdapat sapi lokal, namun terdapat 691 sapi impor untuk RPH Cirangrang dan 226 sapi impor di RPH Regol. Jumlah sapi termasuk sapi lokal dan sapi impor selama satu bulan untuk setiap RPH dapat dilihat pada Gambar 1.

Aktivitas pemotongan hewan dibagi menjadi dua shift, yaitu shift pagi dan sore. Berdasarkan observasi langsung, limbah dari kegiatan pemotongan hewan masih belum dimanfaatkan secara optimal. Limbah (darah dan rumen) terbuang selama proses pencucian dan belum ada penanganan lebih lanjut dari pembuangan limbah cair. Kotoran limbah ternak dibuang pada tempat pembuangan akhir secara langsung tanpa penanganan sebelumnya. Seperti disebutkan dalam pengumpulan data, terdapat dua jenis ternak di rumah pemotongan, yaitu sapi lokal dan sapi impor. Berat rata-rata kedua jenis sapi tersebut cukup berbeda, yaitu sapi impor lebih berat daripada sapi lokal. Menurut data yang didapatkan dari rumah potong hewan, berat sapi lokal sekitar 300-400 kg (rata-rata $350 \mathrm{~kg}$ ), sedangkan sapi impor adalah 400-600 (rata-rata $500 \mathrm{~kg}$ ). Mengacu pada pendekatan penelitian Heryadi \& Zali (2017), total berat sapi baik lokal maupun impor selama periode penelitian dapat diestimasi perhitungannya mengikuti persamaan (1). 
Mengacu kepada penelitian Afazeli et al. (2014), perhitungan total produksi biogas per tahun dapat diestimasi perhitungannya mengikuti persamaan (2).

Produksi biogas per tahun $=($ Berat total sapi $x$ proporsi dari unit

potensial penghasil biogas (darah, rumen, dan kotoran) $x 12$ bulan)

Setelah produksi biogas dihitung, maka biogas dapat dikonversi menjadi potensi energi listrik $(\mathrm{kWH})$. Menurut penelitian yang dilakukan oleh Wahyuni (2013), $1 \mathrm{~m}^{3}$ biogas dapat dikonversi menjadi 4,7 kWH energi listrik. Dengan demikian, total potensi energi listrik yang dapat dihasilkan dapat dihitung dengan mengikuti persamaan (3) di bawah ini.

Total Potensi Energi Listrik $=$ Total produksi biogas per tahun $x$ 4,7kWH

Selanjutnya besaran biogas yang dihasilkan, dibandingkan dengan kebutuhan listrik Kota Bandung yang dilihat dari rata-rata penggunaan listrik di Kota Bandung selama lima tahun terakhir. Selanjutnya, persentase kontribusi biogas untuk suplai energi listrik dapat diestimasikan terhadap seluruh sektor pada umumnya dan sektor rumah tangga pada khususnya.

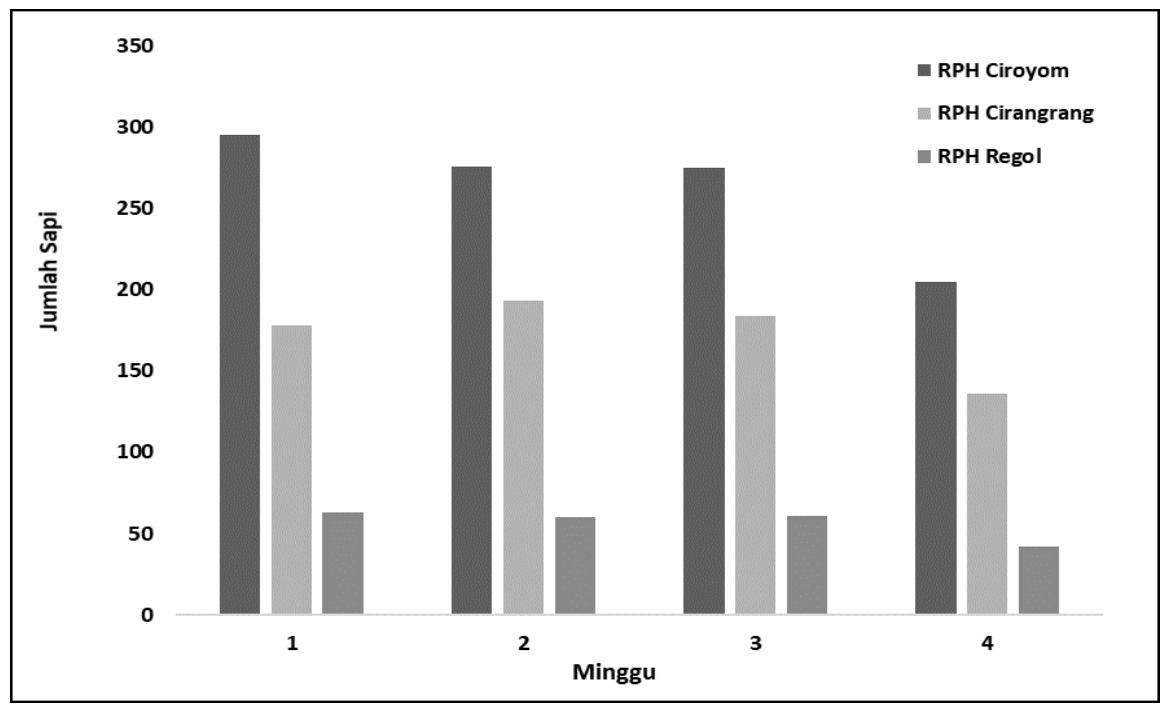

Sumber: Rumah Potong Hewan Ciroyom, Cirangrang, dan Regol, 2017

\section{Gambar 1. Jumlah Sapi di Setiap RPH dalam Satu Bulan}

\section{Hasil dan Pembahasan}

\section{Estimasi Produksi Biogas}

Hal pertama yang harus dilakukan untuk menghitung potensi biogas dari rumah potong hewan adalah mengidentifikasi jumlah sapi lokal dan sapi impor dari setiap RPH di Kota Bandung. Dengan menggunakan persamaan (1), total berat sapi di area Ciroyom adalah $535.650 \mathrm{~kg}$. Dengan menggunakan prosedur yang sama berat total sapi dari RPH Cirangrang dan Regol dapat dihitung seperti yang ditunjukkan pada Tabel 1. 
Tabel 1. Berat Total Sapi di Setiap Rumah Potong Hewan

\begin{tabular}{lccc}
\hline \multirow{2}{*}{ RPH } & \multicolumn{3}{c}{ Berat $\mathbf{( K g )}$} \\
\cline { 2 - 4 } & Lokal & Impor & Total \\
\hline Ciroyom & 17.150 & 519.500 & 536.650 \\
Cirangrang & - & 355.500 & 355.500 \\
Regol & - & 116.000 & 116.000 \\
\hline Sumber: Analisis Penulis, 2017 & &
\end{tabular}

Berdasarkan hasil perhitungan dari ketiga RPH, total berat sapi terbesar dihasilkan di RPH Ciroyom, kemudian diikuti oleh RPH Cirangrang dan Regol. Hal tersebut dikarenakan jumlah sapi yang dipotong di area Ciroyom paling banyak dibandingkan dengan kedua area lainnya, serta pada area Ciroyom terdapat sapi lokal yang dipotong.

Hasil berat sapi yang telah didapat merupakan input untuk membuat biogas. Menurut penelitian Afazeli et al. (2014), Fathurrohman, Hari, Zukhriyah, \& Adam (2015), Hanif (2010), dan Mahmud (2015), biogas didapatkan dari bahan kering setiap bagian tubuh sapi (darah, rumen, dan kotoran) dengan proporsi yang berbeda-beda seperti ditunjukkan pada Tabel 2.

Tabel 2. Proporsi Unit Potensial Biogas dari 1 Kg Berat Sapi

\begin{tabular}{|c|c|c|c|c|c|}
\hline $\begin{array}{c}\text { Unit } \\
\text { Potensial } \\
\text { Biogas }\end{array}$ & $\begin{array}{l}\text { Proporsi } \\
\quad(k g)\end{array}$ & $\begin{array}{l}\text { Persentase berat } \\
\text { kering }(\%)\end{array}$ & $\begin{array}{c}\text { Berat kering } \\
(\mathrm{kg})\end{array}$ & $\begin{array}{c}\text { Hasil } \\
\text { biogas } \\
\left(\mathrm{m}^{3} / \mathbf{k g}\right)\end{array}$ & Literatur \\
\hline Darah & 0,035 & 18 & 0,0063 & 0,6 & $\begin{array}{l}\text { Afazeli et al. (2014); } \\
\text { Lestari, Hudoyo, \& } \\
\text { Dartosukarno (2010) }\end{array}$ \\
\hline Rumen & 0,1 & 16 & 0,016 & 0,3 & Afazeli et al. (2014) \\
\hline Kotoran & 0,056 & 20 & 0,0112 & 0,3 & $\begin{array}{l}\text { Fathurrohman, Hari, } \\
\text { Zukhriyah, \& Adam (2015); } \\
\text { Hanif (2010); Mahmud } \\
(2015)\end{array}$ \\
\hline
\end{tabular}

Tabel 2 menunjukkan bahwa dari $1 \mathrm{~kg}$ sapi terdapat 0,035 $\mathrm{kg}$ darah dan dapat menghasilkan biogas sebanyak $0,6 \mathrm{~m}^{3}$. Selain itu, terdapat rumen sebesar $0,1 \mathrm{~kg}$ yang mampu menghasilkan 0,3 $\mathrm{m}^{3}$ biogas. Kemudian 0,056 kg kotoran juga dapat menghasilkan kurang lebih $0,3 \mathrm{~m}^{3}$ biogas. Setelah itu, hasil proporsi pembentukan setiap unit potensial penghasil biogas dari sapi (darah, rumen, dan kotoran) dikalikan jumlah berat sapi yang terdapat pada Tabel 1 dengan mengikuti persamaan (2).

Tabel 3. Estimasi Produksi Biogas pada Setiap Rumah Potong Hewan

\begin{tabular}{ccccc}
\hline \multirow{2}{*}{ Unit Potensial Biogas } & \multicolumn{4}{c}{ Produksi Biogas $\mathbf{~ m}^{3} /$ tahun) } \\
\cline { 2 - 4 } & Ciroyom & Cirangrang & Regol & Total \\
Darah & 23.517 & 15.672 & 5.126 & 44.314 \\
Rumen & 29.863 & 19.901 & 6.509 & 56.272 \\
Kotoran & 20.904 & 13.931 & 4.556 & 39.391 \\
Total & 74.284 & 49.503 & 16.191 & 139.977 \\
\hline
\end{tabular}

Tabel 3 menunjukkan produksi biogas dari seluruh limbah sapi di seluruh rumah potong hewan yaitu sebesar $139.977 \mathrm{~m}^{3} /$ tahun. Jumlah tersebut menunjukkan potensi biogas di Kota Bandung sebesar $139.977 \mathrm{~m}^{3} /$ tahun. Dibandingkan dengan kota lainnya di dunia, Kota Tehran di Iran mampu menghasilkan 9 juta $\mathrm{m}^{3} /$ tahun biogas dari limbah peternakan sapi (Afazeli et al., 2014). Kota Sabah di Malaysia mampu menghasilkan biogas 
sebesar 248,83 juta $\mathrm{m}^{3}$ /tahun dari limbah peternakan sapi (Abdeshahian, Lim, Ho, Hashim, \& Chew Tin Lee, 2016). Jumlah biogas yang dapat dihasilkan oleh Kota Bandung lebih sedikit apabila dibandingkan dengan kota lainnya di dunia. Hal tersebut dikarenakan pada penelitian ini ruang lingkupnya lebih kecil jika dibandingkan dengan lainnya, yaitu rumah potong hewan milik pemerintah dan swasta.

Tabel 3 menunjukkan bahwa RPH Ciroyom diestimasi menghasilkan biogas sebesar $74.284 \mathrm{~m}^{3} /$ tahun. Melalui prosedur yang sama, produksi biogas dari RPH Cirangrang and RPH Regol dapat diprediksi seperti yang ditunjukkan pada Tabel 3. Dari unit potensial biogas, bagian sapi yang paling banyak berkontribusi dalam produksi biogas adalah rumen, yaitu $56.272 \mathrm{~m}^{3} /$ tahun diikuti oleh darah dan kotoran. Rumen adalah bagian lambung yang di dalamnya terdapat bahan pakan yang telah dimakan serta mikroba yang memfermentasikan bahan pakan tersebut (Usman, 2013). RPH yang paling banyak menghasilkan biogas adalah Ciroyom diikuti Cirangrang dan Regol. Proporsi estimasi biogas yang dihasilkan dari tempat dan unit potensial biogas dari sapi ditunjukkan secara rinci pada Gambar 2.

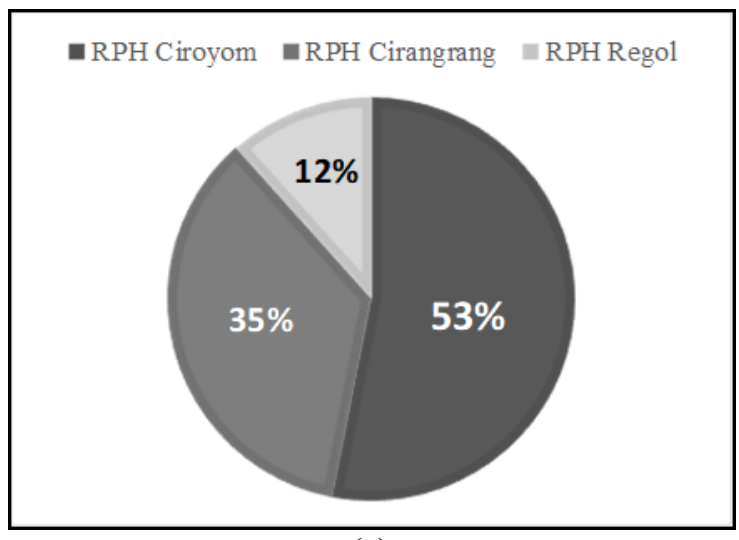

(a)

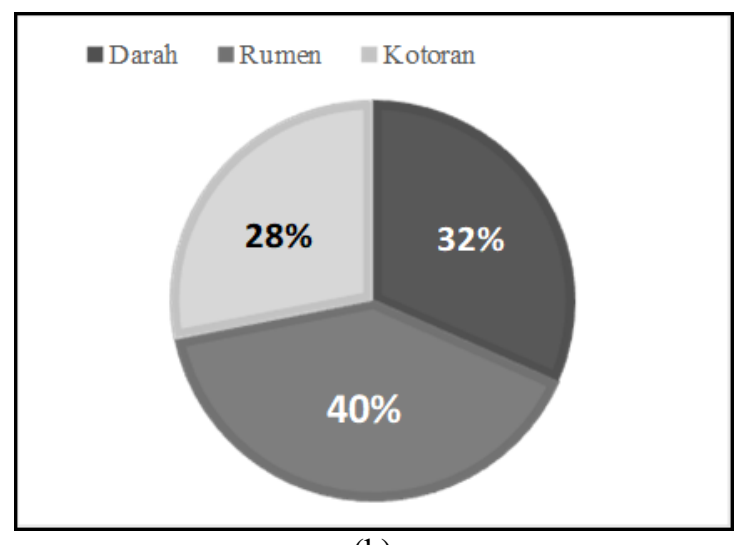

(b)

Sumber: Rumah Potong Hewan Ciroyom, Cirangrang, dan Regol, 2017

\section{Gambar 2. (a) Persentase Produksi Biogas dari Setiap RPH dan (b) Unit Potensial Biogas dari Sapi}

RPH Ciroyom berkontribusi sebanyak 53\% dari total produksi biogas. Hal tersebut karena area Ciroyom merupakan pusat RPH di Kota Bandung, sehingga jumlah sapi yang dipotong lebih banyak daripada kedua rumah potong lainnya. Semakin banyak jumlah sapi, semakin besar potensi biogas yang dapat dihasilkan (Dharma \& Ridhuan, 2014). Dari bagian sapi, kontribusi rumen lebih besar karena proporsi rumen dalam $1 \mathrm{~kg}$ sapi lebih besar daripada darah dan kotoran. Proporsi rumen mencapai $10 \%$ dari berat sapi dibandingkan dengan berat darah yaitu 3,5\% dan kotoran 5,6\%. Hasil penelitian sejalan dengan penelitian yang dilakukan oleh Afazeli et al. (2014) yang menyatakan bahwa rumen dapat menghasilkan lebih banyak biogas daripada darah. Selain itu, Darmawati, Mahadi, \& Sukma (2015) menjelaskan bahwa jumlah rumen sapi berkolerasi positif dengan hasil biogas yang dapat dibentuk selama eksperimen. Hal tersebut karena jumlah bakteri terbanyak terdapat pada rumen sapi, yaitu 1-10 miliar/ml cairan rumen (Basri, 2016). Salah satu jenis bakteri yang ada dalam rumen adalah bakteri metanogenik yang berperan dalam pembentukan gas metan dengan cara menguraikan bahan organik menjadi metan secara anaerob (Ihsan et al., 2013; Yazid \& Bastianudin, 2011). Tingginya bahan organik dalam rumen dapat mempercepat pembentukan biogas (Manendar, 2010 dalam Ihsan et al., 2013). 


\section{Studi Pemanfaatan Biogas dari Limbah Rumah Potong Hewan ...}

\section{Estimasi Potensi Energi Listrik}

Potensi energi listrik dari RPH Ciroyom selama satu tahun dapat diperkirakan sebesar 349,13 MWh, dengan menggunakan persamaan (3). Dengan prosedur perhitungan yang sama, potensi energi listrik dari RPH Cirangrang dan RPH Regol dapat diprediksi seperti ditunjukkan pada Gambar 3. Perbedaan jumlah produksi biogas mempengaruhi besaran energi listrik yang dihasilkan. Perbedaan ini disebabkan oleh jumlah dan jenis sapi tiap RPH. Sapi impor dan lokal memiliki berat yang berbeda. Berat badan sapi impor lebih besar daripada sapi lokal karena faktor genetik (Wiyatna, 2007). Di RPH Ciroyom, jumlah sapi hampir dua kali lipat dibandingkan RPH Cirangrang. RPH Regol memiliki jumlah sapi paling sedikit daripada kedua RPH lainnya. Pada saat penelitian, tidak ditemukan sapi lokal di RPH Cirangrang dan RPH Regol, dan berdasarkan hasil wawancara, semua RPH lebih banyak menerima sapi impor daripada sapi lokal.

Pada penelitian ini besaran energi listrik yang dapat dihasilkan oleh Kota Bandung lebih kecil dibandingkan dengan kota-kota pada penelitian lainnya. Di Kota Malang, potensi listrik dari kotoran sapi yang dapat dihasilkan sebesar $3.760 \mathrm{kWh}$ per hari dari 4.000 ekor sapi (Saputri et al., 2014). Selain itu, potensi listrik yang dapat dihasilkan adalah sebesar $77.428 \mathrm{kWh}$ per hari 47 peternakan di Kota Tehran (Sefeedpari, Rafiee, \& Akram, 2012). Adanya perbedaan dari kedua penelitian tersebut karena area penelitian yang berbeda. Penelitian ini dilakukan pada area rumah potong hewan, sedangkan kedua penelitian tersebut pada area peternakan yang memiliki jumlah sapi lebih banyak.

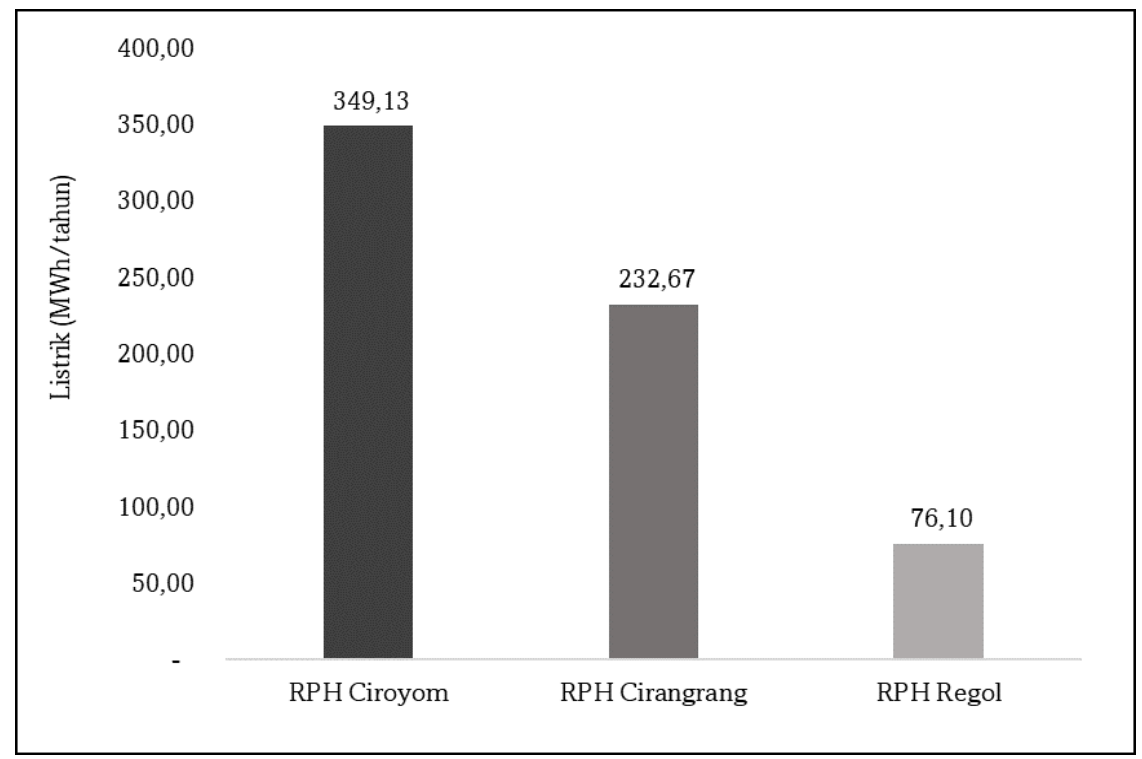

Sumber: Rumah Potong Hewan Ciroyom, Cirangrang, dan Regol, 2017

\section{Gambar 3. Estimasi Energi Listrik Yang Dihasilkan dari Pemanfaatan Biogas pada Setiap RPH}

\section{Kontribusi Biogas dalam Memenuhi Suplai Energi Listrik di Kota Bandung}

Data permintaan energi listrik di Kota Bandung didapat dari Badan Pusat Statistik Kota Bandung seperti ditunjukkan pada Tabel 4. Berdasarkan data yang didapat, hampir setiap tahunnya kebutuhan listrik di Kota Bandung selalu meningkat dari sektor rumah tangga maupun sektor-sektor lain. Hal tersebut berbanding lurus dengan peningkatan jumlah penduduk di Kota Bandung. Dibandingkan dengan jumlah produksi biogas dengan jumlah kebutuhan rata-rata energi listrik Kota Bandung, maka produksi biogas dari RPH dapat mengakomodasi kebutuhan listrik sebesar 16,2\% untuk seluruh sektor. Namun jika dibandingkan dengan kebutuhan rumah tangga, produksi biogas dapat mengakomodasi 
kebutuhan listrik hingga mencapai 41,9\%. Hasil potensi biogas yang dapat menjadi energi listrik dari rumah potong hewan sejalan dengan salah satu upaya Pemerintah Kota Bandung dalam menyediakan sumber energi terbarukan yang dapat melestarikan lingkungan hidup (Pemerintah Kota Bandung, 2012).

Tabel 4. Suplai Energi Listrik dari Perusahaan Listrik Negara (PLN) untuk Kota Bandung

\begin{tabular}{ccc}
\hline \multicolumn{3}{c}{ Energi listrik terjual di Kota Bandung (MWh/tahun) } \\
\hline Tahun & Seluruh sektor* & Sektor rumah tangga $^{* *}$ \\
2012 & 3.850 & 1.624 \\
2013 & 4.033 & 1.499 \\
2014 & 4.163 & 1.573 \\
2015 & 4.091 & Data tidak tersedia \\
2016 & 4.180 & 1.588 \\
Rata-rata & $\mathbf{4 . 0 6 3}$ & $\mathbf{1 . 5 7 1}$ \\
\hline
\end{tabular}

Sumber: *BPS Kota Bandung, 2017

**BPS Kota Bandung, 2013-2017

\section{Kesimpulan}

Hasil penelitian ini menunjukkan adanya potensi yang menjanjikan dari pemanfaatan energi terbarukan biogas dari limbah RPH milik Pemerintah dan Swasta di Kota Bandung. Dari ketiga RPH yang diteliti, RPH Ciroyom memiliki potensi terbesar dan limbah rumen sapi adalah yang paling banyak berkontribusi untuk menghasilkan biogas. Penelitian ini selaras dengan penelitian sebelumnya dengan menunjukkan bahwa estimasi potensi biogas tidak hanya berasal dari areal peternakan saja, dalam hal ini berasal dari limbah kotoran hewan, tetapi juga dapat berasal dari RPH dengan memanfaatkan limbah darah dan rumen sebagai potensi penghasil biogas.

Biogas merupakan sumber energi terbarukan yang potensial, murah, dan ramah lingkungan bila dibandingkan dengan sumber energi fosil pada umumnya. Dari aspek lingkungan biogas membantu untuk mengurangi limbah organik dan emisi karbon. Akan tetapi pemanfaatan biogas di Indonesia yang belum optimal dan masih terbatas pada sumber energi untuk kegiatan rumah tangga seperti memasak tentunya menjadi tantangan tersendiri bagi pemerintah maupun sektor swasta untuk dapat memaksimalkan dan memperbesar skala pemanfaatan potensi biogas sebagai sumber energi listirk.

Diperlukannya tata cara, sosialisasi, teknologi konversi, serta perencanaan pemanfaatan biogas dari limbah Rumah Potong Hewan guna mendukung keberlanjutan Peraturan Daerah Kota Bandung Nomor 18 Tahun 2012 tentang energi dan ketenagalistrikan. Hasil penelitian ini menunjukan potensi biogas dari ketiga jenis limbah tersebut jika dioptimalkan dapat menghasilkan kurang lebih sebanyak $139.977 \mathrm{~m}^{3} /$ tahun. Jika dikonversi menjadi energi listrik, potensi biogas ini dapat menghasilkan energi listrik kurang lebih sebesar $658 \mathrm{MWh} /$ tahun.

Untuk mendukung ketahanan energi di Kota Bandung, biogas dari rumah potong hewan dapat berkontribusi sebesar 49,8\% untuk pasokan listrik rumah tangga atau 16,7\% dari total pasokan listrik di Kota Bandung. Sebagai salah satu langkah menuju sustainable smart city sudah saatnya potensi energi baru terbarukan dapat terus dikembangkan dan ditingkatkan lagi proporsi penggunaannya dalam mendukung ketahanan energi Kota Bandung. 


\section{Studi Pemanfaatan Biogas dari Limbah Rumah Potong Hewan...}

\section{Ucapan Terima Kasih}

Penulis mengucapkan terima kasih banyak kepada RPH Ciroyom area Bandung Barat, RPH Cirangrang area Bandung Selatan, dan RPH Regol area Bandung Selatan Kota Bandung atas kerjasama dan bantuan dalam menyediakan data dan kunjungan lapangan guna mendukung penelitian ini. Penulis juga mengucapkan terima kasih kepada Kepala Badan Kesatuan Bangsa dan Pemberdayaan Masyarakat Kota Bandung serta Kepala Dinas Ketahanan Pangan dan Peternakan Provinsi Jawa Barat atas izin yang diberikan untuk melakukan penelitian di RPH Kota Bandung. Selain itu penulis mengucapkan terima kasih banyak kepada Direktorat Riset dan Pengabdian Masyarakat, Direktorat Jenderal Penguatan Riset dan Pengembangan Kementerian Riset, Teknologi, dan Pendidikan Tinggi Republik Indonesia atas dana penelitian Tahun 2017 dengan nomor kontrak penelitian: 0786/K4/KM/2018, 12 Februari 2018 kategori Penelitian Dosen Pemula dengan Surat Perjanjian Penugasan Pelaksanaan Penelitian Dosen Pemula dengan nomor: 001/SP4/LP2M-UTAMA/III/2018.

\section{Daftar Pustaka}

Abdeshahian, P., Lim, J. S., Ho, W. S., Hashim, H., \& Chew Tin Lee. (2016). Potential of biogas production from farm animal waste in Malaysia. Renewable and Sustainable Energy Reviews, 60, 714-723. doi:10.1016/j.rser.2016.01.117.

Afazeli, H., Jafari, A., Rafiee, S., \& Nosrati, M. (2014). An investigation of biogas production potential from livestock and slaughterhouse wastes. Renewable and Sustainable Energy Reviews, 34, 380-386. doi:10.1016/j.rser.2014.03.016.

Badan Pusat Statistik (BPS). (2017). Statistik Indonesia 2017. Jakarta: Badan Pusat Statistik Indonesia.

Badan Pusat Statistik (BPS) Kota Bandung. (2016). Jumlah penduduk menurut kelompok umur dan jenis kelamin Kota $\quad$ Bandung 2016. $\quad$ Retrieved from https://bandungkota.bps.go.id/statictable/2017/08/29/104/jumlah-penduduk-menurut-kelompokumur-dan-jenis-kelamin-di-kota-bandung-2016-.html.

Badan Pusat Statistik (BPS) Kota Bandung. (2017). Luas wilayah menurut kecamatan di Kota Bandung 2017. Retrieved from https://bandungkota.bps.go.id/statictable/2018/07/11/154/luas-wilayah-menurutkecamatan-di-kota-bandung-km2-2017.html.

Basri, E. (2016). Potensi dan pemanfaatan rumen sapi sebagai bioaktivator. In Prosiding Seminar Nasional Agroinovasi Spesifik Lokasi Untuk Ketahanan Pangan Pada Era Masyarakat Ekonomi ASEAN (pp. 10531059).

Darmawati, D., Mahadi, I., \& Sukma, G. M. (2015). Pemanfaatan cairan isi rumen sapi dan sampah dalam memproduksi biogas sebagai pengembangan handout biologi. Jurnal Biogenesis, 12(1), 7-14. Retrieved from https://ejournal.unri.ac.id/index.php/JPSB/article/view/5107.

Dehkordi, A. K. F., Shamsabadi, A. A., Pishkar, I., \& Nafchi, S. P. M. (2015). Potential of biogas production from livestock manure in order to reduce the environmental pollution in Chamnar, Iran. Dama International, 4(3), 93-98. Retrieved from http://sciencejournal.in/data/documents/Trends-Life-Sci.-4-3-16.pdf.

Dewan Energi Nasional. (2016). Indonesia energy outlook 2016. Jakarta: Kementerian Energi dan Sumber Daya Mineral Republik Indonesia.

Dharma, U. S., \& Ridhuan, K. (2014). Kajian potensi sumber energi biogas dari kotoran ternak untuk bahan bakar alternatif di Kecamatan Kalirejo Kabupaten Lampung Tengah. Turbo, 3(2), 34-41.

Elizabeth, R., \& Rusdiana, S. (2011). Efektivitas pemanfaatan biogass sebagai sumber bahan bakar dalam mengatasi biaya ekonomi rumah tangga di Perdesaan. Jakarta: Badan Penelitian dan Pengembangan Departemen Pertanian Republik Indonesia.

Fathurrohman, A., Hari, M. A., Zukhriyah, A., \& Adam, M. A. (2015). Persepsi peternak sapi dalam pemanfaatan kotoran sapi menjadi biogas di Desa Sekarmojo Purwosari Pasuruan. Jurnal Ilmu-Ilmu Peternakan, 25(2), 36-42. doi:10.21776/ub.jiip.2015.025.02.05.

Hanif, A. (2010). Studi pemanfaatan biogas sebagai pembangkit listrik 10kw kelompok Tani mekarsari Desa Dander Bojonegoro menuju desa mandiri energi. Fakultas Teknologi Industri Institut Teknologi Sepuluh November. 
Herawati, T. (2012). Refleksi sosial dari mitigasi emisi gas rumah kaca pada sektor peternakan di Indonesia. Wartazoa, 22(1), 35-46. $\quad$ Retrieved from http://medpub.litbang.pertanian.go.id/index.php/wartazoa/article/download/973/982.

Heryadi, A. Y., \& Zali, M. (2017). Konsumsi daging sapi di Kabupaten Pamekasan. In Seminar Nasional Peternakan 3 tahun 2017. Makassar: Universitas Hasanuddin Makassar. Retrieved from http://www.unhas.ac.id/semnas_peternakan/wp-content/uploads/2018/07/35_Yudi-madura_275282.pdf.

Ho, C. S., Matsuoka, Y., Simson, J., \& Gomi, K. (2013). Low carbon urban development strategy in Malaysia The case of Iskandar Malaysia development corridor. Habitat International, 37, 43-51. doi:10.1016/j.habitatint.2011.12.018.

Hozairi, H., Bakir, B., \& Buhari, B. (2012). Pemanfaatan kotoran hewan menjadi energi biogas untuk mendukung pertumbuhan UMKM di Kabupaten Pamekasan. In Prosiding InSINas 2012 (pp. 93-98).

Ihsan, A., Bahri, S., \& Musafira, M. (2013). Produksi biogas menggunakan cairan isi rumen sapi dengan limbah cair tempe. Online Jurnal of Natural Science, 2(2), 27-35. Retrieved from http://jurnal.untad.ac.id/jurnal/index.php/ejurnalfmipa/article/view/1644.

Intergovernmental Panel on Climate Change (IPCC). (2007). Climate change 2007: Impacts, adaptation and vulnerability. Contribution of working group II to the fourth assessment report of the intergovernmental panel on climate change. (M. L. Parry, O. F. Canziani, J. P. Palutikof, P. van der Linden, \& C. E. Hanson, Eds.). Cambridge, UK

International Energy Agency (IEA). (2012). Renewable energy. International Energy Agency.

Lestari, C. M. S., Hudoyo, Y., \& Dartosukarno, S. (2010). Proporsi karkas dan komponen-komponen nonkarkas sapi jawa di rumah potong hewan swasta Kecamatan Ketanggungan Kabupaten Brebes. In Seminar Nasional Teknologi Peternakan dan Veteriner 2010 (pp. 296-300). Bogor: Pusat Penelitian dan Pengembangan Peternakan.

Mahmud, M. (2015). Analisis tekno ekonomi perencanaan pembangkit listrik tenaga anaerobik biogas dengan pemanfaatan kotoran sapi di Desa Galang. Elkha Jurnal Teknik Elektro, 72), 1-7. Retrieved from http://jurnal.untan.ac.id/index.php/Elkha/article/view/12755.

Martinez, J., Dabert, P., Barrington, S., \& Burton, C. (2009). Livestock waste treatment systems for environmental quality, food safety, and sustainability. Bioresource Technology, 100(22), 5527-5536. doi:10.1016/j.biortech.2009.02.038.

Omari, A. M., Kichonge, B. N., John, G. R., Njau, K. N., \& Mtui, P. L. (2014). Potential of municipal solid waste, as renewable energy source - A case study of Arusha, Tanzania. International Journal of Renewable Energy Technology Research, 3(6), 1-9.

Opurum, C. ., Nweke, C. ., Nwanyanwu, C. ., \& Orji, J. . (2017). Biogas production from fish pond effluent supplemented with cow blood meal in a batch anaerobic digester system. Futo Journal Series, 3(1), 166175.

Owusu, P. A., \& Banadda, N. (2017). Livestock waste-to-bioenergy generation potential in Uganda: A review. Journal of Environmental Research, Engineering and Management, 73(3), 45-53. doi:10.5755/j01.erem.73.3.14806.

Pariatamby, A., \& Fauziah, S. H. (2013). Sustainable 3R practice in the Asia and Pacific Regions: The challenges and issues. In Agamuthu Pariatamby \& M. Tanaka (Eds.), Municipal Solid Waste Management in Asia and the Pacific Islands: Challenges and Strategic Solutions (pp. 15-40). Singapore: Springer. doi:10.1007/978-981-4451-73-4_2.

Pemerintah Kota Bandung. (2012). Peraturan Daerah Kota Bandung nomor 18 tahun 2012 tentang Energi dan Ketenagalistrikan. Bandung: Pemerintah Kota Bandung.

PT PLN (Persero) Distribusi Jawa Barat Cabang Bandung. (2016). Jumlah pelanggan, daya tersambung dan energi terjual perusahaan listrik negara Di Kota Bandung, 2016. Retrieved from https://bandungkota.bps.go.id/statictable/2017/08/29/90/jumlah-pelanggan-daya-tersambung-danenergi-terjual-perusahaan-listrik-negara-di-kota-bandung-2016.html.

Rachmawati, S. (2000). Upaya pengelolaan lingkungan usaha peternakan ayam. Wartazoa, 9(2), 73-80.

Ramachandra, T. ., Kamakshi, G., \& Shruthi, B. . (2004). Bioresource status in Karnataka. Renewable and Sustainable Energy Reviews, 8(1), 1-47. doi:10.1016/j.rser.2003.09.001.

Rawung, F. C. (2015). Efektivitas ruang terbuka hijau (RTH) dalam mereduksi emisi gas rumah kaca (GRK) di Kawasan Perkotaan Boroko. Media Matrasain, 12(2), 17-32. Retrieved from 


\section{Studi Pemanfaatan Biogas dari Limbah Rumah Potong Hewan...}

https://ejournal.unsrat.ac.id/index.php/jmm/article/view/9204.

Recebli, Z., Selimli, S., Ozkaymak, M., \& Gonc, O. (2015). Biogas production from animal manure. Journal of Engineering Science and Technology, 196), 722-729. Retrieved from http://jestec.taylors.edu.my/Vol 10 issue 6 June 2015/Volume (10) Issue (6) 722-729.pdf.

Saputri, Y. F., Yuwono, T., \& Mahmudsyah, S. (2014). Pemanfaatan kotoran sapi untuk bahan bakar PLT biogas $800 \mathrm{kw}$ di Desa Babadan Kecamatan Ngajum Malang. Jurnal Teknik Pomits, 1(1), 1-6. Retrieved from http://digilib.its.ac.id/ITS-paper-22121140006421/33637.

Sefeedpari, P., Rafiee, S., \& Akram, A. (2012). Providing electricity requirements by biogas production and its environmental benefit in sample dairy farms of Iran. International Journal of Renewable Energy Research, 2(3), 384-387. Retrieved from https://www.researchgate.net/publication/263568227_Providing_Electricity_Requirements_by_Biogas _Production_and_Its_Environmental_Benefit_in_Sample_Dairy_Farms_of_Iran.

Setiawan, A. I. (2008). Memanfaatkan kotoran ternak. Jakarta: Penerbit Penebar Swadaya.

Tarigan, A. K. M., Sagala, S., Samsura, D. A. A., Fiisabiilillah, D. F., Simarmata, H. A., \& Nababan, M. (2016). Bandung City, Indonesia. Cities, 50, 100-110. doi:10.1016/j.cities.2015.09.005.

Usman, Y. (2013). Pemberian pakan serat sisa tanaman pertanian (jerami kacang tanah, jerami jagung, pucuk tebu) terhadap evolusi pH, N-NH3 dan VFA di dalam rumen sapi. Agripet, 3(2), 53-58. doi:10.17969/agripet.v13i2.821.

Wahyuni, S. (2013). Panduan praktis biogas. Jakarta: Penerbit Penebar Swadaya.

Wiyatna, M. F. (2007). Perbandingan indek perdagingan sapi-sapi Indonesia (Sapi Bali, Madura,PO) dengan Sapi Australian Commercial Cross (ACC). Jurnal Ilmu Ternak, 71), 22-25. doi:10.24198/jit.v7i1.2227.

Worldmeters. (2018). Top 20 largest countries by population. Retrieved from http://www.worldometers.info/world-population/.

Yazid, M., \& Bastianudin, A. (2011). Seleksi mikroba metanogenik menggunakan irradiasi gamma untuk peningkatan efisiensi proses digesti anaerob pembentukan biogas. Jurnal Iptek Nuklir Ganendra, 14(1), 47-55. Retrieved from http://jurnal.batan.go.id/index.php/ganendra/article/view/31.

Yuliana, D. K. (2017). Tingkat emisi gas rumah kaca di Kabupaten Indramayu. Jurnal Sains Dan Teknologi Mitigasi Bencana, 12(2), 1-10. $\quad$ Retrieved from http://ejurnal.bppt.go.id/index.php/JSTMB/article/view/2098. 